\title{
Exploiting heterosis and combining ability in two-line hybrid rice
}

\author{
Mahmoud M. GABALLAH ${ }^{1}$, Aziz F. Abu EL-EZZ ${ }^{1}$, Adel M. GHONEIM ${ }^{2,3}$, Baochang YANG ${ }^{4}$, Langtao \\ $\mathrm{XIAO}^{5}$
}

Received August 22, 2020; accepted December 16, 2020. Delo je prispelo 22. avgusta 2020, sprejeto 16. decembra 2020.

Exploiting heterosis and combining ability in two-line hybrid rice

Abstract: Twenty hybrids were developed from crossing, four environmental genic male sterile (EGMS) lines with five testers in line $\times$ tester mating design to magnitude of heterosis over better parent for grain yield and contributing traits in rice (Oryza sativa L.). Five hybrids 'WTSC9059' × 'Sakha101', 'WTSC9039' × 'Sakha102', 'WTSC9059' × 'Sakha108', 'WTSC9039' × 'Sakha108' and 'WTSC9039' × 'Sakha101' express superior value for number of panicles, fertility percentage, 100 -grain mass, grain yield, apparent heterosis and phenotypic acceptance. The top three heterotic combinations identified for grain yield/ha were 'WTSC9059' × 'Sakha101', 'WTSC9039' $\times$ 'Sakha102' and 'Longping' $\times$ 'Sakha105' which exhibited $100.00,71.51$ and $66.61 \%$ heterobeltiosis, respectively. The lines 'WTSC9059' and "Longping" and testers 'Sakha101', 'Sakha102' and 'Sakha108' was found to be good general combiner for most of the characteristics and could be extensively used in future hybrid rice breeding program. The grain yield was correlated highly significant and positive with panicle exertion, panicle mass, fertility percentage and appearance of heterosis, otherwise the negative correlation and significant was found with flag leaf area.

Key words: heterosis; combining ability; line $\times$ tester; correlation; hybrid rice
Uporaba heteroze in kombinacijske sposobnosti pri dveh linijah hibridnega riža

Izvleček: Dvajset križancev je nastalo iz križanj štirih okoljsko gensko moško sterilnih (EGMS) linij s petimi testerji po principu linija $\times$ tester za povečanje heteroze $\mathrm{v}$ primerjavi $\mathrm{z}$ boljšo starševsko linijo za pridelek zrnja in z njim povezanimi lastnostmi pri rižu (Oryza sativa L.). Pet križancev 'WTSC9059' × 'Sakha101', 'WTSC9039' × 'Sakha102', 'WTSC9059' × 'Sakha108, 'WTSC9039' × 'Sakha108' in 'WTSC9039' × 'Sakha101' ima veliko boljše vrednosti za znake kot so število latov, odstotek plodnosti, masa $100 \mathrm{zrn}$, pridelek zrnja, aparentna heteroza in fenotipska sprejemljivost. Najboljše tri heterotične kombinacije za pridelek zrna na hektar so bile 'WTSC9059' × 'Sakha101', 'WTSC9039' × 'Sakha102' in 'Longping' × 'Sakha105', ki so pokazale 100,$00 ; 71,51$ in $66,61 \%$ heterobeltioze. Liniji 'WTSC9059' in 'Longping' in testerji 'Sakha101', 'Sakha102' in 'Sakha108' so bili prepoznani kot dobri splošni kombinatorji za večino lastnosti in bi lahko bili na široko uporabljeni v bodočih križanjih pri žlahtnenju riža. Pridelek zrnja je zelo značilno pozitivno koreliral $\mathrm{z}$ močjo lata in njegovo maso, odstotkom fertilnosti in pojavom heteroze, nasprotno je bila negativna korelacija s površino najvišjega, zastavnega lista.

Ključne besede: heteroza; kombinacijska sposobnost; linija $\times$ tester; korelacija; hibridni riž

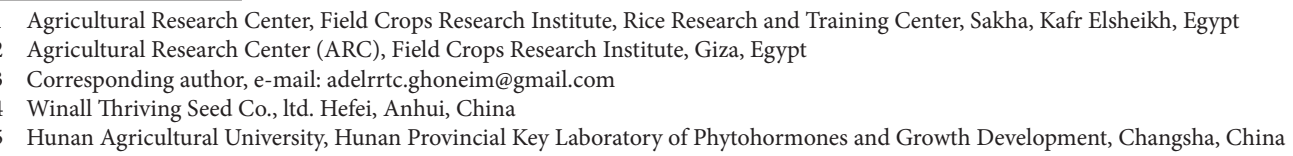




\section{INTRODUCTION}

Rice (Oryza sativa L.) is one of the world's three major food crops and represents an important component of the world's food supply. Hybrid rice technology has contributed significantly toward food security, environmental protection, and employment opportunities (Gramaje et al., 2020). Generating hybrid rice, which presents a higher grain yield than inbred rice varieties, is one of the most important applications of heterosis in agriculture (Liu et al., 2020). Rice is a self-pollinating crop, and nearly all traditional rice cultivars are inbred lines. Since the 1970s, hybrid seed production has mainly used twoline or three-line hybrid systems (Chang et al., 2016). The three-line system is based on a cytoplasmic male sterile (CMS) line, a restorer line (to produce $\mathrm{F}_{1}$ hybrid seeds) and a CMS maintainer line (to maintain the CMS line). The two-line hybrid system is based on environmentally sensitive genetic male sterility (Yu et al., 2020)" and it usually uses photoperiod- and thermo-sensitive genic male sterile (PTGMS) lines as maternal parents to produce hybrid seeds. PTGMS lines are sterile under restrictive conditions (high temperatures and long days) but become fertile under permissive conditions such as low temperatures and short days (Lan et al., 2019). Environment-sensitive genic male sterility is controlled by nuclear gene expression, which is influenced by environmental factors such as temperature, day length, or both (Chang et al., 2016). In the two-line system, certain lines, referred to $S$ lines, can be either male sterile (functionally female) or male (produces viable pollen) depending upon temperature and day length. Under temperature / day length combined condition, the $S$ lines are crossed as females to fertile inbred lines to produce hybrid seed, while under separate temperature/day length combination, the same lines are allowed to self-pollinate and produce viable seeds to maintain a source. The success of hybrid rice technology primarily depends on genetic purity, timely availability and the affordability of hybrid seed costs to the farmers (Singh and Ram, 2012).

The line $\times$ tester analysis is a powerful tool to discriminate the good and poor combiners for choosing appropriate parental material in successful hybrid breeding program. It gives reliable information about the nature and degree of gene action and combining ability effects existent in the genetic materials (Akter et al., 2010). Breeding value can be deduced from the general and specific combining abilities for key desirable traits, as well as from the phenotypic and genotypic value of the parental forms for highly inheritable traits. The general combining ability (GCA) of a given parent for a particular trait is defined by the mean value of the trait in the half-sibling progeny of this parent. The specific combining ability
(SCA) reflects how a particular pair of parents contributes to the presence of a particular trait level in the hybrid progeny. SCA is defined as interaction between a pair of the parents for a progeny trait. Studies on the genetic basis of heterosis for polygenic traits in various crops have shown that heterosis is the result of partial to complete dominance, overdominance, and epistasis and it may be a combination of all these (Gokulakrishnan and Kumar, 2013). Evidence of real overdominance for quantitative traits is hard to find. However, apparent overdominance caused by nonallelic interaction and linkage disequilibrium is a common contributor to heterosis (Dan et al., 2019 and Hijam et al., 2019). The present study was conducted with objective to determine the heterosis levels in generated hybrids, estimate GCA of the pollinator tester and EGMS lines, determine SCA of the generated hybrid crosses, and estimate the nature and degree of gene actions and heritability.

\section{MATERIALS AND METHODS}

\subsection{GENETIC MATERIALS}

A total of 20 testcrosses were developed by applying a line $\times$ tester mating design using four EGMS lines $(\mathrm{S})$ and five pollinators tester $(\mathrm{P})$ as described by Kempthorne (1957). The nine parents were cultivated thrice at an interval of 10 days to ensure synchronization in flowering for the purpose of hybridization in Sanya, Hainan Province, China, 2017 rice growing season. The hybrid crosses and their parents were evaluated at the experimental field of the Winall Thriving Seed Co., (WTSC) Farm in 2018 rice growing season in Hefei, Anhui Province, China. The origin, pedigree, salience and feature of nine rice genotypes were illustrated in Table 1. At 2017 rice growing season thirty days after sowing, the seedlings were transplanted by hand into the paddy field with each plot containing 5 rows with 10 plants per row at a space of $20 \mathrm{~cm} \times 20 \mathrm{~cm}$. Twenty-five days after pollination, the $\mathrm{F}_{1}$ seeds were harvested, dried by air, threshed by hand and stored at room temperature. The $F_{1}$ hybrids' seeds and their parents (pollinator lines and EGMS lines) were nursed in the May $1^{\mathrm{ST}}$ 2018. Thirty days later, the seedlings were transplanted into the paddy field with one seedling per hill using a randomized complete block design and three replications for each genotype. Each plot contained 15 rows with 20 plants per row at a space of $20 \mathrm{~cm} \times 15 \mathrm{~cm}$, each test entry consisted 15 rows of $2 \mathrm{~m}$ length, the plant area for each genotype was $6 \mathrm{~m}^{2}$. All practices recommended package for planting, transplanting, N, P, K and Zn fertilizers, water management and plant protection were followed. The soil of the 

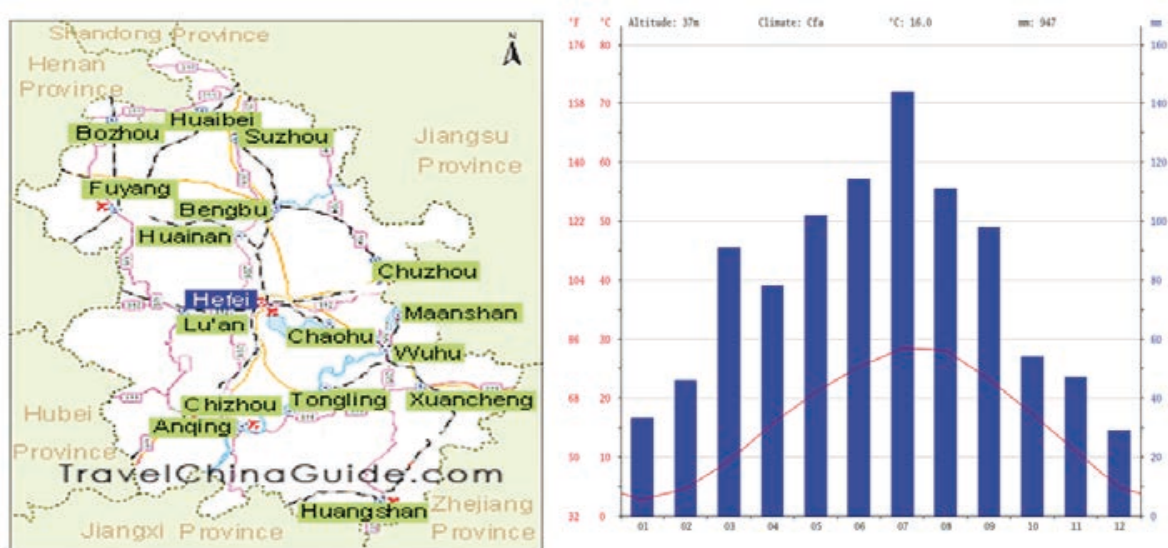

Figure 1: Illustrate of the geographical location and average of temperature and humidity of the experimental site.

experimental site was clay, with organic matter contents of $17.65 \%$. The geographical location and climate of the experimental site were given in Fig. 1.

\subsection{FIELD EVALUATION}

After harvest maturity, all the panicles of randomly selected 10 plants were harvested manually, put them into a Nylon mesh bag, sun-dried and threshed. Grain yield $\left(t \mathrm{ha}^{-1}, \mathrm{GY}\right)$ for each plot was recorded from a 33hill sample, adjusted to a moisture content of $14 \%$ and expressed in $\mathrm{kg} \mathrm{ha}^{-1}$. Important agronomic traits including days to $50 \%$ heading $(\mathrm{DTH})$, plant height $(\mathrm{cm} ; \mathrm{PH})$, SPAD-chlorophyll values (SPAD; CC), flag leaf angle $\left({ }^{\circ}\right.$; FAG) and area $\left(\mathrm{cm}^{2} ; \mathrm{FAR}\right)$, panicle length $(\mathrm{cm} ; \mathrm{PL})$, number of panicles per plant (NP), panicle mass ( $\mathrm{g}$; PW), fertility percentage (\%; FP) and 100-grain mass (g; HGW) according to standard evaluation system (IRRI, 2002). Panicle exertion (PE) refers to the proportion of the panicle that is exerted from the flag leaf sheath to the total panicle length after the full blooming, which is expressed in percentage.

\section{$P E(\%)=($ Length $(\mathrm{cm})$ of exerted panicle/Total length $(\mathrm{cm})$ of panicle $) \times 100$}

Grain type (GT) as per 1-9 scale, where 1, 3, 5, 9 scale based on length-to-width ratio: slender, $>3.0$; medium, 2.1 to 3.0 ; bold 1.1 to 2.0 ; and round, $<1.0$, respectively. Apparent heterosis $(\mathrm{AH})$ subjective superiority of a hybrid over its parents or a check variety based on visual observation and expressed as vigorous vegetative growth in the field. Phenotypic acceptability (PA), pollen sterility/fertility were monitored and lines were evaluated on a single plant basis for phenotypic acceptability (on a
1-9 scale, where 1 is unacceptable, 3 is poor, 5 is fair, 7 is good and 9 is excellent) according to (Khush et al., 2003).

\subsection{STATISTICAL ANALYSIS}

\subsubsection{Analysis of variance and correlation coefficient of traits}

Analysis of variance (ANOVA) was performed using a general linear model

$$
Y i j k=\mu+P i j+r k+e i j k
$$

Whereas, $Y_{i j k}=$ the observed value, $\mu=$ the population mean, $P_{i j}=$ the mean effect of the $i j$ th genotype, $\mathrm{R}_{k}=$ the $k$ th replication effect and eijk is the experimental error assumed with $i j k$ th observation and is assumed to be normally and independently distributed with a mean of zero and variance of $\sigma^{2}$. Mean comparisons among genotypes were evaluated using Tukey's HSD test ( $p$ 0.05). Correlation among values of the different traits investigated were performed based on Pearson's productmoment correlation as implemented.

\subsubsection{Estimation of heterosis}

Heterobeltiosis or better parent heterosis (BPH) was estimated in terms of percent increase or decrease of the $\mathrm{F}_{1}$ hybrid over its better parent (Fehr, 1987).

$$
B P H(\%)=[\overline{F 1}-\overline{B P} / B P] \times 100
$$

Significance of better parent heterosis was determined following the "t" test suggested by (Wynne et al., 1970). 


$$
B P((t))^{-}=(F 1)^{-}-B P / \sqrt{ }((2 / r) E M S)
$$

Where, $F_{1}=$ Mean of the $F_{1}$ hybrid for a trait, $B P=$ Mean of better parent in the cross, and $E M S=$ Error mean square.

\subsubsection{Combining ability analysis}

Estimates of GCA and SCA effects and their variances were computed using line $\times$ tester analysis according to (Singh \& Chaudhary, 1985). The analysis was done using the Agrobase software statistical package. Additive and dominance genetic variances $\left(\sigma_{A}^{2}\right.$ and $\left.\sigma_{D}^{2}\right)$ were calculated by taking inbreeding coefficient $(F)$ equal to one; that is, $F=1$ because both lines and testers were inbred. Significance test for general and specific combining ability effects were performed using $t$-test. The relative mass of additive versus non-additive type of gene actions was calculated as described by (Verma \& Srivastra, 2004).

$$
\left(\sigma_{\text {gca }}^{2} / \sigma_{s c a}^{2}\right) \text {, and }\left(\sigma_{D}^{2} / \sigma_{A}^{2}\right)^{1 / 2}
$$

\subsubsection{Heritability}

Broad $\left(\mathrm{H}^{2}\right)$ and narrow sense $\left(\mathrm{h}^{2}\right)$ heritability for the measured traits were estimated based on Griffiths et al.) (2000).

\section{RESULTS}

\subsection{MEAN PERFORMANCE}

Means of the parental genotypes and relative $F_{1}$ crosses for the fifteen studied characters showed that the earlier heading was obtained in genotypes 'Longping' $\times$ 'Sakha108', 'Sakha107', 'WTSC9059' × 'Sakha105' and 'Longping' $\times$ 'Sakha105' while the delayed heading genotypes were 'WTSC9369' × 'Sakha101', 'WTSC9369' × 'Sakha108', 'WTSC9039' × 'Sakha108' and 'WTSC9369' $\times$ 'Sakha107'. The tallest plants were observed for 'WTSC9369' × 'Sakha101', 'WTSC9039' × 'Sakha108' and 'WTSC9369' $\times$ 'Sakha108' crosses while minimum for 'WTSC9059', 'WTSC9039' and 'Longping' lines. The highest chlorophyll content values were observed for parents 'Sakha105', 'WTSC9039', 'Sakha107' and cross 'WTSC9059' × 'Sakha101', otherwise the lowest values for 'WTSC9369' × 'Sakha107', 'WTSC9039' × 'Sakha107', 'WTSC9369' × 'Sakha105' and 'WTSC9369', respectively. With respect to flag leaf angle $\left(^{\circ}\right)$ the erect flag leaves were found for crosses 'Longping' $\times$ 'Sakha108', 'WTSC9369' $\times$ 'Sakha108' and 'Longping' $\times$ 'Sakha105' while the widest flag leaf angle was found with genotypes 'WTSC9059'

\begin{tabular}{|c|c|c|c|c|}
\hline No. & Entries & Pedigree & Origin & Salience and feature \\
\hline 1 & 'WTSC9039' & $18925 / 8152011 \mathrm{SH}_{7}$ & China & $\begin{array}{l}\text { Indica/Japonica type, EGMS line, short grain, plant height } 90 \mathrm{~cm} \text {, grain } \\
\text { yield 7-7.20 } \mathrm{tha}^{-1} \text {, resistance to blast, sensitive to drought and salinity. }\end{array}$ \\
\hline 2 & ‘WTSC9059’ & $\mathrm{Y}_{585 / 18925} 2011 \mathrm{SH}_{8}$ & China & $\begin{array}{l}\text { Indica/Japonica type, EGMS line, short grain, plant height } 82 \mathrm{~cm} \text {, grain } \\
\text { yield } 4-4.50 \mathrm{t} / \mathrm{ha} \text {, resistance to blast, sensitive to drought and salinity. }\end{array}$ \\
\hline 3 & 'WTSC9369' & $18925 / 9451 / 958 / 9054$ & China & $\begin{array}{l}\text { Indica/Japonica type, EGMS line, short grain, plant height } 88 \mathrm{~cm} \text {, grain } \\
\text { yield 5-5.20 t/ha, resistance to blast, sensitive to drought and salinity. }\end{array}$ \\
\hline 4 & 'Longping' & \multicolumn{2}{|c|}{$\begin{array}{l}\text { Long ping seed companyChina } \\
\text { ltd. }\end{array}$} & $\begin{array}{l}\text { Indica/Japonica type, EGMS line, short grain, plant height } 80 \mathrm{~cm} \text {, grain } \\
\text { yield } 4.30-4.50 \mathrm{t} / \mathrm{ha} \text {, resistance to blast, sensitive to drought and salinity. }\end{array}$ \\
\hline 5 & 'Sakha101' & Giza 176 / Milyang 79 & Egypt & $\begin{array}{l}\text { Japonica type, pollinator, short grain, plant height } 90 \mathrm{~cm} \text {, high yield } 10.5 \\
\text { t/ha, susceptible to blast and sensitive to drought and salinity }\end{array}$ \\
\hline 6 & 'Sakha102' & GZ 4096-7-1 / Giza 177 & Egypt & $\begin{array}{l}\text { Japonica type, pollinator, short grain, plant height } 110 \mathrm{~cm} \text {, high yield } \\
10.0 \mathrm{t} / \mathrm{ha} \text {, resistance to blast and sensitive to drought and salinity }\end{array}$ \\
\hline 7 & 'Sakha105’ & $\begin{array}{l}\text { GZ } 5581-46-3 / \text { GZ } 43 \\
7-1-1\end{array}$ & Egypt & $\begin{array}{l}\text { Japonica type, pollinator, short grain, plant height } 103 \mathrm{~cm} \text {, high yield } \\
10.0 \mathrm{t} / \mathrm{ha} \text {, resistance to blast and sensitive to drought and salinity }\end{array}$ \\
\hline 8 & 'Sakha107’ & Giza 177 / BL1 & Egypt & $\begin{array}{l}\text { Japonica type, pollinator, short grain, plant height } 106 \mathrm{~cm} \text {, high yield } \\
10.0 \text { t/ha, resistance to blast and tolerance to drought and moderate tol- } \\
\text { erance to salinity }\end{array}$ \\
\hline 9 & 'Sakha108' & $\begin{array}{l}\text { 'Sakha101'/ HR5 } \\
\text { B-3-2-3 //'Sakha101' }\end{array}$ & gypt & $\begin{array}{l}\text { Japonica type, pollinator, short grain, plant height } 90 \mathrm{~cm} \text {, high yield } 10.5 \\
\text { t/ha, resistance to blast and sensitive to drought and salinity }\end{array}$ \\
\hline
\end{tabular}

Table 1: Origin, pedigree, salience and feature of nine rice genotypes

WTSC, Winall Thriving Seed Company ltd. 


\section{產|}

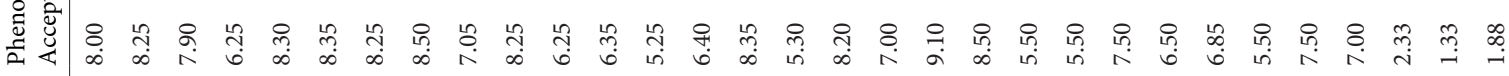
苛 :

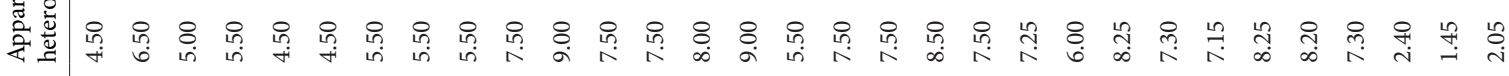

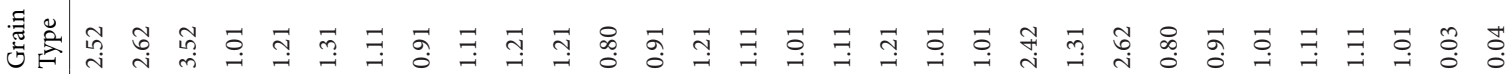
穿

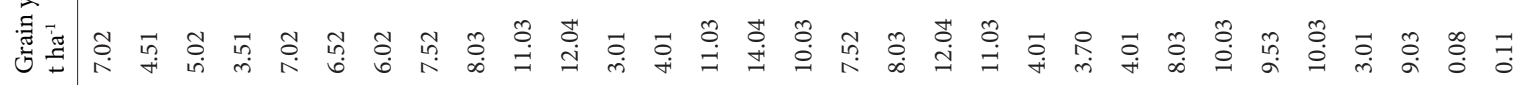
表

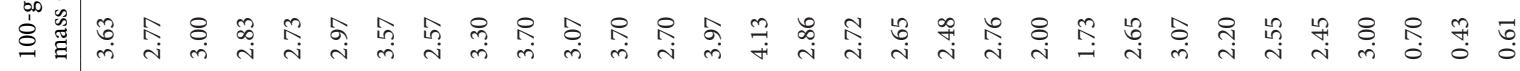
䆑焉

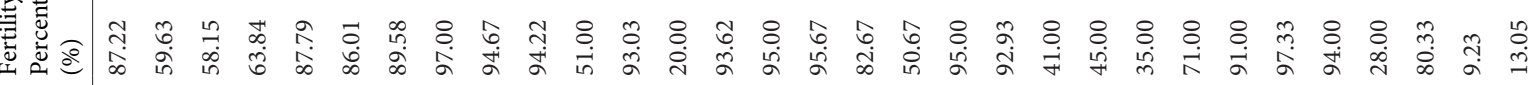

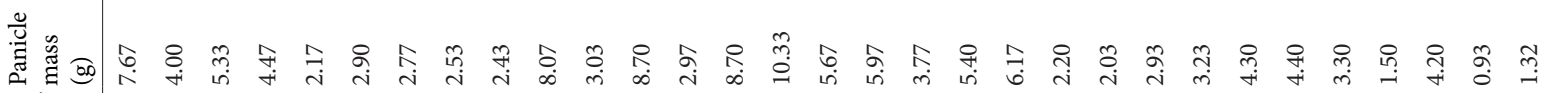

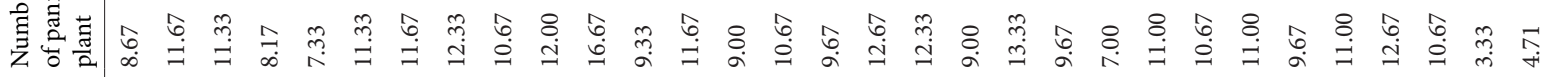

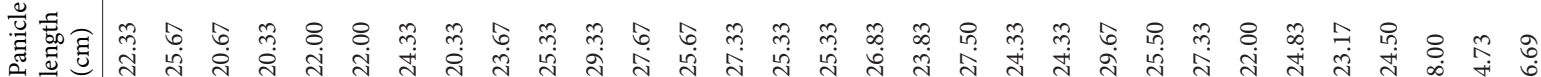

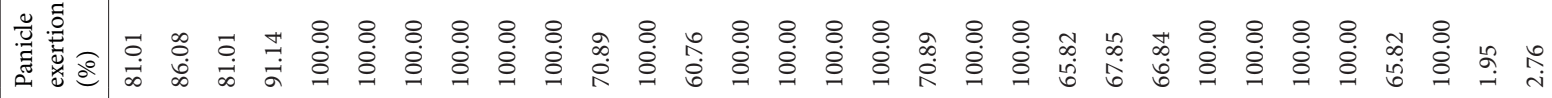

樆

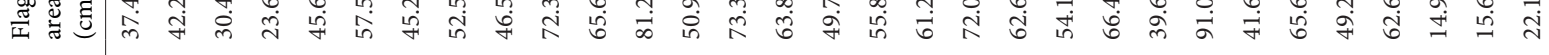

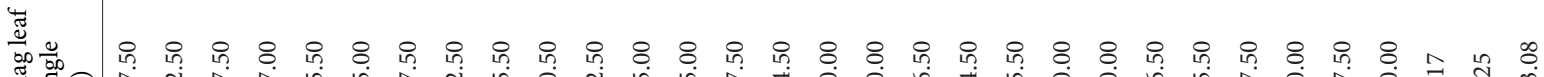

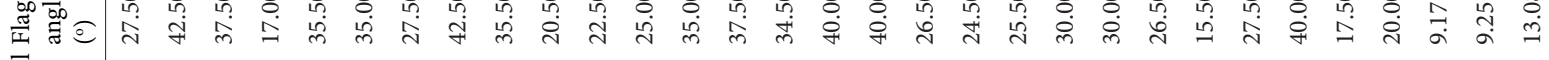
育

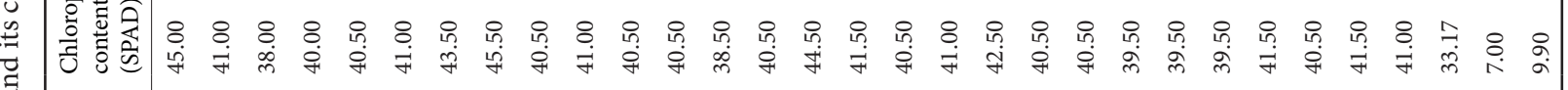

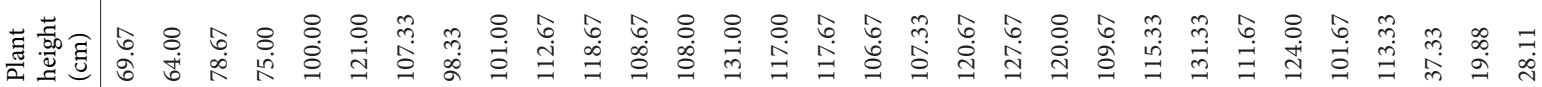

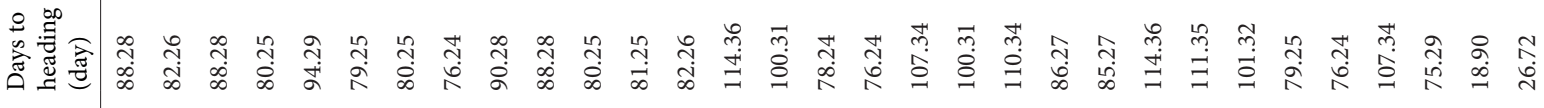

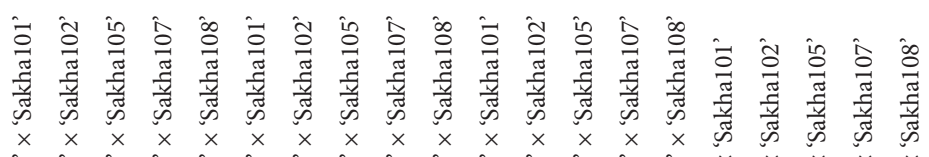

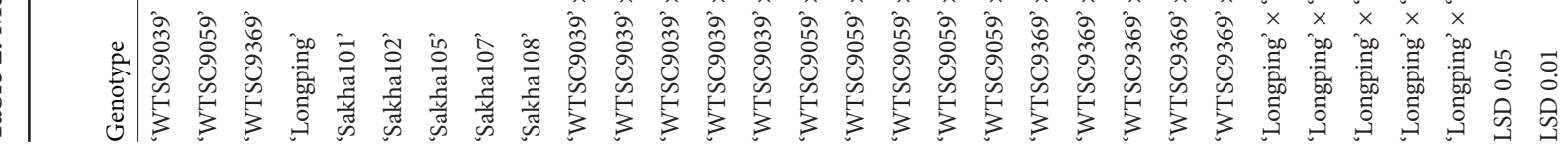


$\times$ 'Sakha105' $\left(40^{\circ}\right)$, 'Longping' $\times$ 'Sakha102'(40 $\left.{ }^{\circ}\right)$, 'WTSC9059' (42.5 $\left.{ }^{\circ}\right)$ and 'Sakha107'(42.5 '). Regardless the small flag leaf area was found for 'Longping' $\times$ 'Sakha108', 'Longping, 'WTSC9369' and 'WTSC9039' crosses and the largest area for crosses 'WTSC9039' $\times$ 'Sakha101', 'WTSC9039' × 'Sakha108', 'WTSC9039' × 'Sakha105' and 'WTSC9369' x 'Sakha108'. The crosses 'Longping' $\times$ 'Sakha101', 'Longping' $\times$ 'Sakha102', 'Longping' $\times$ 'Sakha105' and 'Longping' $\times$ 'Sakha108' had the complete panicle exertion percentage while the partial and lowest values were obtained from hybrid combinations 'WTSC9039' × 'Sakha107', 'WTSC9369' × 'Sakha102', 'Longping' $\times$ 'Sakha107' and 'WTSC9369' $\times$ 'Sakha107'.

The highest panicle length $(\mathrm{cm})$ was observed with crosses 'WTSC9059' × 'Sakha108', 'WTSC9039' × 'Sakha105', 'WTSC9039' × 'Sakha102' and 'WTSC9369' $\times$ 'Sakha105', respectively. However, the lowest panicle length found for genotypes 'Longping' $\times$ 'Sakha108', 'Longping', 'Sakha107' and 'WTSC9369'. The maximum number of panicles/ plants were obtained from crosses 'WTSC9059' × 'Sakha105' (12.67), 'Longping' × 'Sakha107' (12.67), 'WTSC9369' × 'Sakha101' (13.33) and 'WTSC9039' × 'Sakha102' (16.67) compared to genotypes 'WTSC9369' × 'Sakha105' (7), 'Sakha101' (7.33), 'Longping' (8.17) and 'WTSC9039' (8.67) with smaller panicles number. The heaviest panicle mass were found for crosses 'WTSC9039' $\times$ 'Sakha101', 'WTSC9039' × 'Sakha105', 'WTSC9039' × 'Sakha108' and 'WTSC9059' × 'Sakha101' that ranged from $8.07 \mathrm{~g}$ and $10.33 \mathrm{~g}$ while the lowest panicle mass was found for genotypes 'Longping' × 'Sakha107', 'WTSC9369' × 'Sakha105', 'Sakha101' and 'WTSC9369' × 'Sakha102' which ranged between $1.5 \mathrm{~g}$ to $2.2 \mathrm{~g}$. Maximum fertility percentage was found for genotypes 'WTSC9059' × 'Sakha108' (95 \%), 'WTSC9059' × 'Sakha102' (95.67 \%), 'Sakha107' (97 \%) and 'Longping' $\times$ 'Sakha102' (97.33\%) while the minimum fertility was noted with 'WTSC9039' × 'Sakha107' (20\%), 'Longping' $\times$ 'Sakha107' (28 \%), 'WTSC9369' × 'Sakha107' (35\%) and 'WTSC9369' $\times$ 'Sakha102' (41 \%). The highest 100-grain mass (g) was found for crosses 'WTSC9039' × 'Sakha101', 'WTSC9039' × 'Sakha105', 'WTSC9039' $\times$ 'Sakha108' and 'WTSC9059' $\times$ 'Sakha101' which ranged from $3.7 \mathrm{~g}$ to $4.13 \mathrm{~g}$. While, lowest 100 -grain mass was gained from crosses 'Longping' $\times$ 'Sakha108', 'WTSC9369' × 'Sakha105', 'WTSC9369' × 'Sakha102' and 'Longping' $\times$ 'Sakha101'. The highest grain yield was found for crosses 'WTSC9369' × 'Sakha101' (11.03 t/ha), 'WTSC9039' × 'Sakha102' (12.04 t/ha), 'WTSC9059' × 'Sakha108' (12.04 t/ha) and 'WTSC9059' × 'Sakha101' (14.04 t/ha), while the lowest grain yield was found with genotypes 'WTSC9039' × 'Sakha105' (3.01 t/ha), 'Longping' $\times$ 'Sakha107' (3.01 t/ha), 'Longping' (3.51 t/ha) and
'WTSC9369' $\times$ 'Sakha105' (3.7 t ha $\left.{ }^{-1}\right)$. The short grain type was found with genotype 'WTSC9039' × 'Sakha105', 'WTSC9369' $\times$ 'Sakha108', 'Sakha107' and 'WTSC9039' $\times$ 'Sakha107', while the longest grain type was found for genotypes 'WTSC9039', 'WTSC9059', 'WTSC9369' × 'Sakha107' and 'WTSC9369'. The highest apparent heterosis was obtained from crosses 'Longping' $\times$ 'Sakha102', 'WTSC9059' × 'Sakha108', 'WTSC9039' × 'Sakha102' and 'WTSC9059' × 'Sakha101' which ranged from 8.25 to 9, however the lowest mean values were observed with genotypes 'Longping' × 'Sakha108', 'WTSC9039', 'Sakha101' and 'Sakha102' that ranged between 2.4 to 4.5. Regardless phenotypic acceptability, the desired mean values 8.35 , 8.5, 8.5 and 9.1 were found with genotypes 'WTSC9039' $\times$ 'Sakha108', 'Sakha105', 'WTSC9059' × 'Sakha108' and 'WTSC9059' $\times$ 'Sakha107', respectively, otherwise the lowest mean values were obtained from crosses 'Longping' $\times$ 'Sakha108', 'Longping' × 'Sakha107', 'WTSC9039' $\times$ 'Sakha105' and 'WTSC9059' × 'Sakha101', respectively.

Pearson's correlation revealed that all yield component traits were positively correlated with GY except for FAR and highly significant for traits PE, PW, FP and $\mathrm{AH}$ otherwise the negative correlation and significant was found with AH (Table 3). DTH was correlated significant and positive with FAG and AH. PH correlated significant and positive with CC, FAG, PL, FP, HGMW and $\mathrm{AH}$ while negative and significant with GT. CC was correlated significant and positive with FAR, FP, HGWM and PA. The positive and significant correlation was found among FAG and PL, HGW and $\mathrm{AH}$ otherwise the correlated negative and significant with GT. PE has positive correlation and significant with PW, FP and GY while negative and significant with GT. The positive correlation and significant was found between PL and HGW, $\mathrm{AH}$ and PA. NPP has significant and positive correlation with $\mathrm{AH}$. The significant correlation and positive was found among PW and FP, HGW and GY. FP has positive and negative significant correlation with GY and GT, respectively. The positive and significant correlation was found with HGW, AH and PA.

\subsection{HETEROSIS PERCENTAGE}

The degree of heterosis showed over better parent (Table 4). Days to heading; heterosis percent over better parent showed highly significant and negative which ranged from -5.00 ('Longping' $\times$ 'Sakha105') to 6.18\% ('Longping' $\times$ 'Sakha108'). Three hybrids out from twenty crosses exhibited negative significant heterosis for days to heading. The plant height, desirable highly significant and negative heterosis over better parent was found for cross 'Longping' $\times$ 'Sakha108'. Four hybrids exhibited 
Table 3: Correlation between studied agronomic traits

\begin{tabular}{|c|c|c|c|c|c|c|c|c|c|c|c|c|c|c|}
\hline & DTH & $\mathrm{PH}$ & CC & FAR & FAG & $\mathrm{PE}$ & $\mathrm{PL}$ & NPP & $\mathrm{PM}$ & FP & HGM & GY & GT & $\mathrm{AH}$ \\
\hline $\mathrm{PH}$ & $0.44^{\star *}$ & & & & & & & & & & & & & \\
\hline $\mathrm{CC}$ & 0.05 & $0.32^{\star}$ & & & & & & & & & & & & \\
\hline FAR & -0.16 & 0.16 & $0.35^{\star}$ & & & & & & & & & & & \\
\hline FAG & $0.35^{\star}$ & $0.78^{\star *}$ & 0.27 & 0.02 & & & & & & & & & & \\
\hline $\mathrm{PE}$ & -0.14 & 0.03 & 0.18 & 0.06 & 0.09 & & & & & & & & & \\
\hline PL & 0.26 & $0.71^{\star *}$ & $0.40^{*}$ & 0.27 & $0.74^{\star *}$ & -0.21 & & & & & & & & \\
\hline NPP & -0.01 & 0.13 & 0.01 & -0.07 & 0.09 & -0.15 & 0.06 & & & & & & & \\
\hline PW & 0.13 & 0.04 & 0.21 & 0.07 & 0.23 & $0.40^{*}$ & 0.12 & -0.12 & & & & & & \\
\hline FP & -0.15 & 0.06 & $0.36^{*}$ & 0.14 & 0.12 & $0.93^{\star *}$ & -0.14 & -0.18 & $0.49^{\star *}$ & & & & & \\
\hline HGW & 0.24 & $0.36^{*}$ & $0.57^{\star *}$ & 0.24 & $0.41^{\star}$ & 0.19 & $0.49^{* *}$ & 0.09 & $0.55^{\star *}$ & 0.27 & & & & \\
\hline GY & 0.16 & 0.28 & 0.22 & -0.03 & 0.26 & $0.53^{\star *}$ & 0.03 & 0.24 & $0.45^{\star *}$ & $0.61^{\star \star}$ & 0.17 & & & \\
\hline GT & 0.05 & $-0.35^{\star}$ & -0.06 & 0.24 & $-0.40^{\star}$ & $-0.44^{\star \star}$ & -0.06 & -0.04 & -0.02 & $-0.36^{\star}$ & 0.01 & $-0.36^{\star}$ & & \\
\hline $\mathrm{AH}$ & $0.39^{*}$ & $0.68^{\star *}$ & 0.27 & 0.01 & $0.64^{\star *}$ & -0.16 & $0.72^{\star *}$ & $0.31^{\star}$ & 0.24 & -0.12 & $0.33^{\star}$ & $0.32^{\star}$ & -0.16 & \\
\hline PA & 0.23 & 0.24 & $0.68^{\star *}$ & 0.30 & 0.20 & 0.23 & $0.34^{*}$ & 0.16 & 0.17 & 0.29 & $0.53^{* *}$ & 0.15 & 0.18 & 0.22 \\
\hline
\end{tabular}

${ }^{\star} p=0.05 ;{ }^{* *} p=0.01 ;{ }^{* *} p=0.001$

positively significant heterosis over better parent the degree of heterosis that varied from $1.22 \%$ ('WTSC9059' $\times$ 'Sakha102') to $8.54 \%$ ('WTSC9059' $\times$ 'Sakha101'). For flag leaf angle, heterosis percent over better parent ranged from -2.82\% ('WTSC9059' × 'Sakha101') to $-56.34 \%$ ('WTSC9369' $\times$ 'Sakha108'). Eleven hybrids exhibited desirable significant negative heterosis for this trait over better parent. For flag leaf area, fourteen hybrids had desired significant positive heterosis over better parent. 'WTSC9369' × 'Sakha108' (95.70\%) recorded the highest positive heterosis over better parent followed by 'WTSC9039' × 'Sakha105', 'WTSC9039' $\times$ 'Sakha101', 'WTSC9039' × 'Sakha108' with $79.53 \%$, $58.46 \%$ and $57.70 \%$, respectively. Significant and positive heterosis ranged $8.93 \%$ to $95.70 \%$. Thirteen crosses out from twenty crosses have complete panicle exertion and the heterosis over better parent equal $0.00 \%$. For panicle length $(\mathrm{cm})$, fourteen out from twenty crosses showed highly significant and positive heterosis according to over better parent which ranged $4.52 \%$ to $31.35 \%$. The crosses 'WTSC9039' × 'Sakha101', 'Longping' $\times$ 'Sakha101', 'WTSC9369' × 'Sakha101', 'WTSC9059' × 'Sakha105' and 'Longping' $\times$ 'Sakha107' gave significant and positive heterosis over better parent that ranged between $2.76 \%$ to $38.41 \%$ for number of panicles/plant. The panicle mass had significant and positive heterosis due to better parent found with eight hybrid crosses 'WTSC9039' × 'Sakha101', 'WTSC9039' × 'Sakha105', 'WTSC9039' × 'Sakha108', 'WTSC9369' × 'Sakha101', 'WTSC9059' × 'Sakha108', 'WTSC9059' × 'Sakha102', 'WTSC9059' × 'Sakha105' and 'WTSC9059' × 'Sakha101' were values $5.22 \%, 13.43 \%, 13.43 \%, 15.76 \%, 35.00 \%$, $41.75 \%, 49.25 \%$ and $158.25 \%$, respectively. Among the 20 hybrids, four hybrids showed significantly positive heterosis for fertility percentage were 'WTSC9039' × 'Sakha101', 'WTSC9059' × 'Sakha101', 'WTSC9059' × 'Sakha102' and 'Longping' $\times$ 'Sakha102' which ranged between $7.32 \%$ to $13.16 \%$. Three hybrids out of twenty crosses showed significant and positive heterosis over better parent including 'Longping' $\times$ 'Sakha107' (6.01\%), 'WTSC9039' × 'Sakha108'(9.37\%) and 'WTSC9059' $\times$ 'Sakha101'(49.10\%) for 100-grain mass. Eleven out of twenty crosses had significant and positive heterosis over better parent for grain yield with the best hybrids including 'WTSC9059' × 'Sakha101', 'WTSC9369' × 'Sakha101', 'Longping' $\times$ 'Sakha105' and 'WTSC9039' × 'Sakha102' with $57.12 \%, 66.61 \%, 71.51 \%$ and $100.00 \%$, respectively.

For grain type fifteen from twenty crosses showed significant and negative heterosis over better parent which ranged between $-25.57 \%$ to $-77.27 \%$. For apparent heterosis, eighteen crosses recorded desired significant positive heterosis over better parent. Better parent heterosis ranged between 9.09 and $100.00 \%$. Only one cross 'WTSC9059' × 'Sakha108' had positive and significant heterosis over better parent for phenotypic acceptability.

\subsection{COMBINING ABILITY ANALYSIS}

Analysis of variance of combining ability revealed 


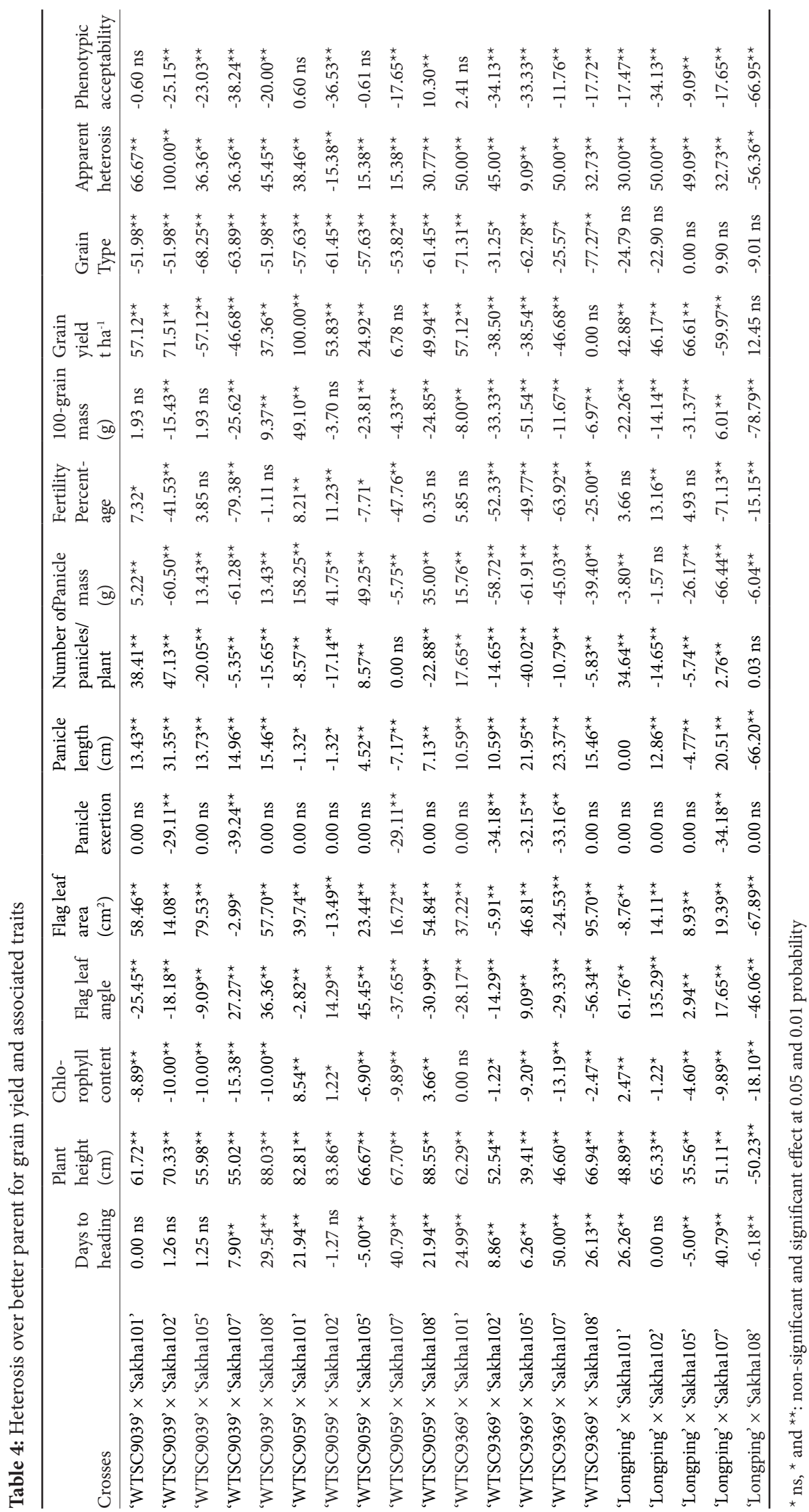


significant differences among genotypes, crosses, lines, testers and line $\times$ tester interactions. The significant differences among the lines, testers and lines $\times$ testers indicated that the genotypes had wide genetic diversity for all traits except days to heading, chlorophyll content, panicle length and apparent heterosis for parents (Table 5 ). The mean sum of squares for crosses was portioned into lines, testers and line $\times$ tester components. In case of lines and testers, significant variances were observed in all traits except number of panicles/ plants. All the line $\times$ tester interactions were significant for all traits studied. Variances of SCA were higher than the GCA variances for all traits. This was further supported by low magnitude of $\sigma^{2} \mathrm{GCA} / \sigma^{2} \mathrm{SCA}$ ratios (Table 6). The ratio of GCA and SCA variances were found to be less than unity for all the characters. $\mathrm{H}^{2}$ ranged from $64.00 \%$ (NPP) to $98.00 \%(\mathrm{PE})$ However, all traits exhibited low $\mathrm{h}^{2}$, ranging from $1 \%$ with $\mathrm{PH}, \mathrm{CC}$ and FAN to $14 \%$ with $\mathrm{PE}$ and FP.

The relative contribution of lines, testers and interaction of line $x$ tester on expression fifteen traits studied, three traits including panicle length, panicle mass and 100-grain mass showed high contribution of lines ranged from 34.19 to 39.18 . Four traits, panicle exertion, panicle mass, fertility percentage and grain yield showed contributed tester ranged from 38.01 to $63.41 \%$ in their hybrids. In other eight traits viz., grain type, phenotypic acceptability, days to heading, flag leaf angle, chlorophyll content, plant height, flag leaf area, number of panicles/ plant, apparent heterosis line $\times$ tester interaction contributed the highest depending on the respective cross showing mean percentage of $1.82,52.72,53.43,54.9$, $56.55,60.98,64.01,69.28,70.51,73.67$ and $79.73 \%$ respectively.

\subsection{COMBINING ABILITY ESTIMATED}

There were significant differences among the genotypes for traits (Table 5), which lead to the combining ability analysis. The increase and decrease in the values of traits desired, positive and negative values of $g_{i}$ were considered. Plant height, days to heading and flag leaf angle negative GCA and SCA effects were desirable, while in other characters positive GCA and SCA effects were desirable.

\subsection{GENERAL COMBINING ABILITY (GCA) EF- FECTS}

GCA effects of fifteen traits showed that 'WTSC9039' was produced highly significant GCA for

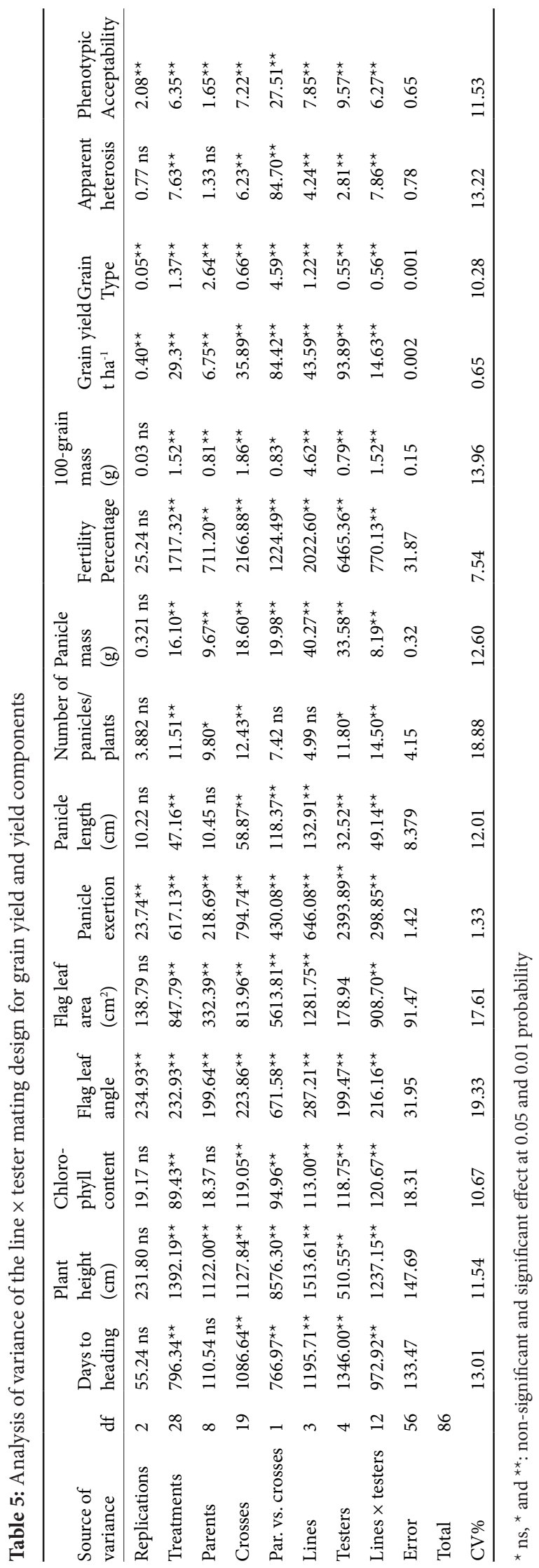

Acta agriculturae Slovenica, 117/1 - 2021 
M. M. GABALLAH et al.

Table 6: Estimates of genetic variances and heritability for grain yield and yield components

\begin{tabular}{|c|c|c|c|c|c|c|c|c|c|c|c|c|c|c|c|}
\hline Traits & DTH & $\mathrm{PH}$ & $\mathrm{CC}$ & FAN & FAR & $\mathrm{PE}$ & PL & NPP & PM & $\mathrm{FP}$ & HGM & GY & GT & $\mathrm{AH}$ & PA \\
\hline Cov H.S (lines & 14.85 & 18.43 & -0.51 & 4.74 & 24.87 & 23.15 & 5.59 & -0.63 & 2.14 & 83.50 & 0.21 & 1.93 & 0.04 & -0.24 & 0.11 \\
\hline Cov H.S (tester) & 31.09 & -60.55 & -0.16 & -1.39 & -60.81 & 174.59 & -1.38 & -0.23 & 2.12 & 474.60 & -0.06 & 6.61 & 0.00 & -0.42 & 0.28 \\
\hline Cov F.S & 342.70 & 316.32 & 33.10 & 67.22 & 235.53 & 356.03 & 20.77 & 2.16 & 8.71 & 977.28 & 0.71 & 16.28 & 0.26 & 1.45 & 2.39 \\
\hline$\sigma_{\mathrm{GCA}}^{2}$ & 3.32 & -3.19 & -0.05 & 0.23 & -2.77 & 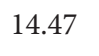 & 0.28 & 6 & 0 & 7 & 1 & 0.62 & .00 & 0.05 & .03 \\
\hline$\sigma_{\mathrm{SCA}}^{2}$ & 279.82 & 363.15 & 34.12 & 61.40 & 272.41 & 99.14 & 13.59 & 3.45 & 2.62 & 246.09 & 0.46 & 4.88 & 0.19 & 2.36 & 1.87 \\
\hline$\sigma_{\mathrm{GCA}}^{2} / \sigma_{\mathrm{SCA}}^{2}$ & 0.01 & -0.01 & 0.00 & 0.00 & -0.01 & 0.15 & 0.02 & -0.02 & 0.12 & 0.17 & 0.02 & 0.13 & 0.02 & -0.02 & 0.01 \\
\hline$\sigma_{\mathrm{A}}^{2}$ & 6.64 & 0.001 & 0.09 & 0.45 & 0.01 & 95 & 0.57 & 0.002 & 61 & 81.53 & 0.02 & 1.24 & 0.01 & .001 & 0.06 \\
\hline$\sigma_{\mathrm{D}}^{2}$ & 279.82 & 363.15 & 34.12 & 61.40 & 272.41 & 99.14 & 13.59 & 3.45 & 2.62 & 246.09 & 0.46 & 4.88 & 0.19 & 2.36 & 1.87 \\
\hline$\left(\sigma_{D}^{2} / \sigma_{A}^{2}\right)^{1 / 2}$ & 42.15 & -56.91 & -362.90 & 0136.40 & -49.26 & 3.43 & 23.92 & -28.54 & 4.31 & 3.02 & 22.90 & 3.93 & 31.17 & -24.85 & 34.05 \\
\hline $\mathrm{H}^{2} \%$ & 83.00 & 89.00 & 80.00 & 86.00 & 89.00 & 98.00 & 82.00 & 64.00 & 97.00 & 93.00 & 90.00 & 67.00 & 75.00 & 90.00 & 90.00 \\
\hline$h^{2} \%$ & 3.00 & 1.00 & 1.00 & 1.00 & 1.00 & 14.00 & 4.00 & 1.00 & 11.00 & 14.00 & 4.00 & 13.00 & 2.00 & 1.00 & 3.00 \\
\hline
\end{tabular}

$\sigma_{\mathrm{GCA}}^{2}$, Variance due to general combining ability (GCA); $\sigma_{\text {SCA }}^{2}$, variance due to specific combining ability (SCA); $\sigma_{\mathrm{GCA}}^{2} / \sigma_{\mathrm{SCA}}^{2}$, GCA variance ratio; $\sigma_{\mathrm{A}}^{2}$, additive genetic variance; $\sigma_{\mathrm{D}}^{2}$, dominance genetic variance; $\left(\sigma_{\mathrm{D}}^{2} / \sigma_{\mathrm{A}}^{2}\right)^{1 / 2}$, degree of dominance; $\mathrm{H}^{2}$, Broad-sense heritability; $\mathrm{h}^{2}$ narrow-sense heritability.

number of panicles/ plants, days to heading, flag leaf area, panicle length, panicle mass, 100-grain mass and apparent heterosis. Therefore, this line was considered as the best general combiner for the respective traits. Similarly, 'WTSC9059' was identified as good general combiner for chlorophyll content, panicle exertion, panicle mass, fertility percentage, 100-grain mass, grain yield, apparent heterosis and phenotypic acceptability.

Otherwise 'WTSC9369' was good combiner for panicle length, flag leaf angle, flag leaf area and grain type. The line 'Longping' was good combiner for panicle exertion, plant height, flag leaf angle, days to heading, fertility percentage and grain yield. The tester 'Sakha101' identified as good combiner for chlorophyll content, panicle exertion, number of panicles per plant, panicle mass, fertility percentage, 100-grain mass, grain yield, apparent heterosis and phenotypic acceptability. Therefore, this line was considered as the best general combiner for the respective traits. The tester 'Sakha102' was good combiner for days to heading, panicle length, number of panicles/ plants, chlorophyll content, grain yield and grain type while"Sakha105" found good combiner for days to heading, plant height, chlorophyll content, flag leaf area, panicle exertion, panicle length and fertility percentage. The tester 'Sakha107' identified as desired combiner for number of panicles/ plants, plant height, grain type and apparent heterosis therefore the tester 'Sakha108' was a good combiner for flag leaf area, panicle exsertion, flag leaf angle, plant height, panicle mass, fertility percentage and grain yield. However, none of parents was observed significant and positive GCA effect for relative water content and number of panicles/plant.

\subsection{SPECIFIC COMBINING ABILITY (SCA) EF- FECTS}

The results of SCA effect of crosses showed that out of twenty hybrid combinations, two of them viz., 'WTSC9039' × 'Sakha107' and 'Longping' x 'Sakha108' produced significant and negative SCA effect for days to heading (Table 8). One and five crosses out from twenty hybrid combination showed significant and negative SCA effects in desirable direction for plant height and flag leaf angle, respectively. For chlorophyll content, five crosses, 'WTSC9039' × 'Sakha108', 'WTSC9059' × 'Sakha108', 'WTSC9369' × 'Sakha108', 'Longping' × 'Sakha105' and 'Longping' $\times$ 'Sakha107' showed significant and positive values for SCA effect. Three hybrid combinations 'WTSC9369' × 'Sakha108', 'Longping' × 'Sakha102' and 'Longping' $\times$ 'Sakha107' showed significant and positive SCA effect of flag leaf area. Ten out from twenty crosses were significant and positive SCA for panicle exertion. Four out of twenty crosses 'WTSC9059' × 'Sakha108', 'WTSC9369' × 'Sakha108', 'Longping' × 'Sakha102' and 'Longping' $\times$ 'Sakha107' showed significant and positive SCA effects for panicle length two hybrid combinations 'WTSC9039' × 'Sakha102' and 'WTSC9059' × 'Sakha105' reported significant and positive SCA effect for number of panicles/plant. For panicle mass, five out from twenty crosses 'WTSC9039' × 'Sakha105', 'WTSC9039' × 'Sakha108', 'WTSC9059' × 'Sakha101', 'WTSC9369' × 'Sakha107' and 'Longping' $\times$ 'Sakha102' had significant and positive SCA effect. Eight hybrid crosses showed significant and positive SCA effect for fertility percentage. Six combinations possessed significant and posi- 
Table 7: General combining ability estimates of lines and testers for traits studied

\begin{tabular}{|c|c|c|c|c|c|c|c|c|}
\hline & $\begin{array}{l}\text { Days to } \\
\text { heading }\end{array}$ & $\begin{array}{l}\text { Plant height } \\
(\mathrm{cm})\end{array}$ & $\begin{array}{l}\text { Chlorophyll } \\
\text { content }\end{array}$ & $\begin{array}{l}\text { Flag leaf } \\
\text { angle }\end{array}$ & $\begin{array}{l}\text { Flag leaf area } \\
(\mathrm{cm} 2)\end{array}$ & $\begin{array}{l}\text { Panicle } \\
\text { exertion }\end{array}$ & $\begin{array}{l}\text { Panicle length } \\
(\mathrm{cm})\end{array}$ & $\begin{array}{l}\text { Number of } \\
\text { panicles/ plant }\end{array}$ \\
\hline \multicolumn{9}{|l|}{ Line } \\
\hline 'WTSC9039' & $-1.51 \mathrm{~ns}$ & $3.78 \mathrm{~ns}$ & $0.79 \mathrm{~ns}$ & $0.72 \mathrm{~ns}$ & $8.98^{\star *}$ & $-2.11^{\star *}$ & $2.18^{\star *}$ & $0.75 \mathrm{~ns}$ \\
\hline 'WTSC9059' & $1.70 \mathrm{~ns}$ & $1.85 \mathrm{~ns}$ & $2.59 \mathrm{~ns}$ & $5.72^{\star *}$ & $0.83 \mathrm{~ns}$ & $5.73^{\star \star}$ & $0.88 \mathrm{~ns}$ & $-0.12 \mathrm{~ns}$ \\
\hline 'WTSC9369' & $10.72^{\star *}$ & $8.78^{\star \star}$ & $0.49 \mathrm{~ns}$ & $-1.88 \mathrm{~ns}$ & $3.05 \mathrm{~ns}$ & $-8.34^{\star *}$ & $1.34^{\star}$ & $-0.65 \mathrm{~ns}$ \\
\hline 'Longping' & $-10.91^{\star *}$ & $-14.42^{\star *}$ & $-3.88^{\star *}$ & $-4.55^{\star \star}$ & $-12.86^{\star *}$ & $4.72^{\star \star}$ & $-4.39^{\star *}$ & $0.02 \mathrm{~ns}$ \\
\hline LSD0.05 & 4.91 & 5.16 & 1.82 & 2.40 & 4.06 & 0.51 & 1.23 & 0.87 \\
\hline LSD0.01 & 6.94 & 7.30 & 2.57 & 3.39 & 5.74 & 0.72 & 1.74 & 1.22 \\
\hline \multicolumn{9}{|l|}{ Tester } \\
\hline 'Sakha101' & $9.27^{\star *}$ & $5.23 \mathrm{~ns}$ & $2.47^{\star}$ & $-0.38 \mathrm{~ns}$ & $0.42 \mathrm{~ns}$ & $11.56^{\star *}$ & $-0.64 \mathrm{~ns}$ & $0.77 \mathrm{~ns}$ \\
\hline 'Sakha102' & $-9.79^{* *}$ & $8.07^{\star}$ & $1.34 \mathrm{~ns}$ & $5.74^{\star \star}$ & $-0.91 \mathrm{~ns}$ & $-4.27^{\star \star}$ & $1.07 \mathrm{~ns}$ & $0.43 \mathrm{~ns}$ \\
\hline 'Sakha105’ & $-11.04^{\star \star}$ & $-5.35 \mathrm{~ns}$ & $1.09 \mathrm{~ns}$ & $0.74 \mathrm{~ns}$ & $3.47 \mathrm{~ns}$ & $3.52^{\star *}$ & $1.94^{\star *}$ & $-0.98^{*}$ \\
\hline 'Sakha107’ & $12.03^{\star *}$ & $-1.02 \mathrm{~ns}$ & $0.59 \mathrm{~ns}$ & $-0.38 \mathrm{~ns}$ & $-6.08^{\star *}$ & $-22.36^{\star \star}$ & $-0.02 \mathrm{~ns}$ & $0.93 \mathrm{~ns}$ \\
\hline 'Sakha108' & $-0.47 \mathrm{~ns}$ & $-6.93^{*}$ & $-5.49^{\star *}$ & $-5.72^{\star \star}$ & 3.11 & $11.56^{\star *}$ & $-2.35^{\star \star}$ & $-1.15^{*}$ \\
\hline LSD0.05 & 5.49 & 5.77 & 2.03 & 2.68 & 4.54 & 0.57 & 1.37 & 0.97 \\
\hline LSD0.01 & 7.76 & 8.16 & 2.87 & 3.80 & 6.42 & 0.80 & 1.94 & 1.37 \\
\hline Line & $\begin{array}{l}\text { Panicle mass } \\
(\mathrm{g})\end{array}$ & $\begin{array}{l}\text { Fertility Per- } \\
\text { centage }\end{array}$ & $\begin{array}{l}\text { 100-grain } \\
\text { mass }(\mathrm{g})\end{array}$ & $\begin{array}{l}\text { Grain yield } \\
\mathrm{t} \mathrm{ha}^{-1}\end{array}$ & Grain Type & $\begin{array}{l}\text { Apparent } \\
\text { heterosis }\end{array}$ & $\begin{array}{l}\text { Phenotypic } \\
\text { Acceptability }\end{array}$ & \\
\hline \multicolumn{9}{|l|}{ Line } \\
\hline 'WTSC9039' & $1.45^{\star \star}$ & $-1.95 \mathrm{~ns}$ & $0.67^{\star *}$ & $-0.03 \mathrm{~ns}$ & $-0.14^{\star *}$ & $0.55^{\star *}$ & $-0.16 \mathrm{~ns}$ & \\
\hline 'WTSC9059' & $1.38^{\star *}$ & $11.48^{\star *}$ & $0.21^{\star}$ & $2.07^{\star *}$ & $-0.12^{\star *}$ & $0.25 \mathrm{~ns}$ & $0.93^{* *}$ & \\
\hline ‘WTSC9369’ & $-1.53^{\star *}$ & $-15.34^{\star *}$ & $-0.31^{\star *}$ & $-2.10^{\star *}$ & $0.43^{\star \star}$ & $-0.10 \mathrm{~ns}$ & $0.04 \mathrm{~ns}$ & \\
\hline 'Longping' & $-1.30^{* *}$ & $5.81^{\star *}$ & $-0.57^{\star *}$ & $0.07^{\star}$ & $-0.18^{\star *}$ & $-0.70^{* *}$ & $-0.82^{\star \star}$ & \\
\hline LSD0.05 & 0.24 & 2.40 & 0.17 & 0.06 & 0.04 & 0.38 & 0.34 & \\
\hline LSD0.01 & 0.34 & 3.39 & 0.24 & 0.08 & 0.06 & 0.53 & 0.49 & \\
\hline \multicolumn{9}{|l|}{ Tester } \\
\hline 'Sakha101' & $2.37^{\star *}$ & $20.96^{\star *}$ & $0.44^{\star \star}$ & $3.28^{\star *}$ & $-0.15^{\star *}$ & $0.43^{\star}$ & $1.33^{\star *}$ & \\
\hline 'Sakha102' & $-1.02^{\star *}$ & $-1.07 \mathrm{~ns}$ & $-0.14 \mathrm{~ns}$ & $0.64^{\star \star}$ & $0.21^{\star \star}$ & $0.15 \mathrm{~ns}$ & $-1.02^{\star *}$ & \\
\hline 'Sakha105’ & $0.16 \mathrm{~ns}$ & $6.35^{\star *}$ & $-0.10 \mathrm{~ns}$ & $-2.19^{\star *}$ & $-0.12^{\star \star}$ & $-0.06 \mathrm{~ns}$ & $0.23 \mathrm{~ns}$ & \\
\hline 'Sakha107' & $-2.05^{\star \star}$ & $-38.91^{\star *}$ & $0.00 \mathrm{~ns}$ & $-3.49^{\star *}$ & $0.26^{\star *}$ & $0.28 \mathrm{~ns}$ & $0.03 \mathrm{~ns}$ & \\
\hline 'Sakha108' & $0.54^{\star \star}$ & $12.67^{\star *}$ & $-0.20^{*}$ & $1.77^{\star \star}$ & $-0.20^{\star *}$ & $-0.81^{\star *}$ & $-0.57^{\star *}$ & \\
\hline LSD0.05 & 0.27 & 2.68 & 0.19 & 0.07 & 0.05 & 0.42 & 0.39 & \\
\hline LSD0.01 & 0.38 & 3.79 & 0.26 & 0.09 & 0.07 & 0.59 & 0.54 & \\
\hline
\end{tabular}

ns, and ${ }^{*}$ and ${ }^{* *}$ : nonsignificant and significant effect at 0.05 and 0.01 probability.

tive SCA effect for 100-grain mass with combinations of 'WTSC9039' × 'Sakha105', 'WTSC9039' × 'Sakha108', 'WTSC9059' × 'Sakha101', 'WTSC9369' × 'Sakha108', 'Longping' $\times$ 'Sakha102' and 'Longping' $\times$ 'Sakha107' trait.

Significant and positive SCA effects were observed in nine hybrid combinations for grain yield including 'WTSC9039' × 'Sakha102', 'WTSC9039’ × 'Sakha108',
'WTSC9059' × 'Sakha101', 'WTSC9059' × 'Sakha107', 'WTSC9369' × 'Sakha101', 'WTSC9369' × 'Sakha107', 'WTSC9369' × 'Sakha108', 'Longping' $\times$ 'Sakha102' and 'Longping' $\times$ 'Sakha105'. Among the nine crosses which depicted highly significant positive SCA effects for grain yield showed high heterosis. Ten and seven out from twenty crosses showed significant and positive SCA effect for grain type and apparent heterosis. The crosses 


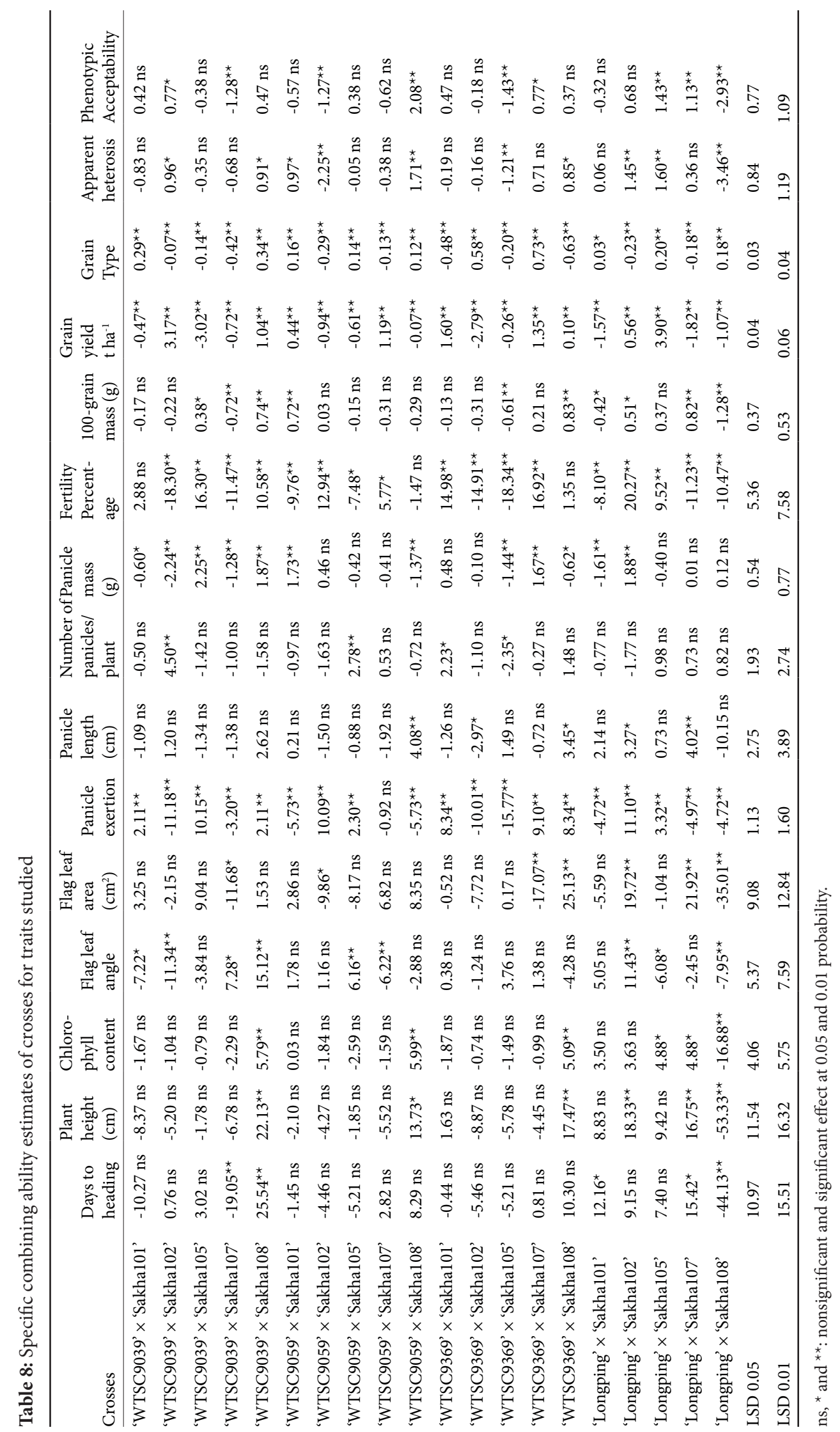


'WTSC9039' × 'Sakha102', 'WTSC9059' × 'Sakha108', 'WTSC9369' × 'Sakha107', 'Longping' × 'Sakha105' and 'Longping' $\times$ 'Sakha107' reported significant and positive SCA effect for phenotypic acceptability.

\section{DISCUSSION}

Grain yield, being a complex quantitative trait, is controlled and influenced by yield contributing components, such as spikelet number, grain filling and grain mass. The present study the hybrid combinations 'WTSC9369' $\times$ 'Sakha101', 'WTSC9039' × 'Sakha102', 'WTSC9059' × 'Sakha108' and 'WTSC9059' $\times$ 'Sakha101'had more than $11 \mathrm{t} \mathrm{ha}^{-1}$ grain yield/ha-1 superior than all parents were used and also the highest in grain yield components, panicle length, fertility percentage, panicle mass and 100-grain mass. These combinations can be exploited as anew hybrids for high yield potentials and good agronomic traits. Overall, hybrids performed better for GY and yield-related traits compared with the parental lines and also showed evident hybrid vigor. The days to heading is important trait that needs to be investigated in every generation and days to maturity and panicle length that needs to be selected in early segregating generation (Ganapati et al., 2020). Jaiswal and Jaiswal 2019 mentioned that the genotype Hubr 16 showed the highest mean value for grain yield and yield contributing traits like panicle length and seeds / panicle followed by Basmati 370. Super hybrid varieties have increased rice yield potential by $12 \%$ compared with ordinary hybrid and inbred varieties. The higher grain yield of super hybrid varieties was attributed to improvement in both source and sink (Zhang et al., 2009). The hybrid varieties produced grain yield of $12 \mathrm{t} \mathrm{ha}^{-1}$ in on-farm demonstration fields, $8-15 \%$ higher than the hybrid check varieties (Peng et al., 2008). Agronomic characteristics that are useful for rice breeding, such as large panicles and flowering habit have good panicle uniformity, concentrated flowering periods and good panicle exertion rates, which would be more conducive to hybrid seed production (El-namaky, 2018).

Correlation coefficients are used to measure relationship between two variables as evident from positive correlation of yield components with GY except for FAR and highly significant for PE, PM, FP and AH traits, however, the negative correlation and significant was found with AH (Table 3). (Yu et al., 2020 found the correlation between the introgression rate of the Habataki pedigree and yield related traits, whereas the introgression rate was significantly negatively correlated to 1000 -grain mass. Li et al. (2019) found that correlations between agronomic traits and yield depend on the rice variety. The improve- ment in GY should focus on increasing the FGN, TGW, GP, PH, PL, GPP, SS, decreasing PN and LW. Gramaje et al. (2020) showed that the GCA effects were poorly correlated with specific combining ability (SCA) effects and hybrid performance, while SCA was positively correlated to heterosis estimates for all traits although it was only correlated with Gy for per se performance.

Genetic parameter analysis indicated the presence of significant differences among the lines, testers and lines $\times$ testers refer the genotypes had wide genetic diversity among themselves for all traits except days to heading, chlorophyll content, panicle length and apparent heterosis for parents. The significance of variance due to lines and testers confirmed a prevalence of additive variance while significant differences for line $\times$ tester among all the characters, indicating the importance of both additive and non-additive types of gene action occur within parents. Additive effects are important for the fixation of the trait and for early selection of the plants. The dominance to additive variance ratio (D/A) could be used for quantitative evaluations at each single QTL through genetic analysis in the heterotic populations (Liu et al., 2020). GCA analysis seeks to facilitate breeding through effective and efficient selection of inbred lines for a cross based on additive and additive $\times$ additive gene effects. Moreover, GCA analysis maximize additive gene effect that increases the selection efficiency of breeders in selecting elite inbred parents with better performance (Ullah Zaid et al., 2019)we calculated the GCA effect values of 33 parents of hybrid rice and sequenced them to identify genome-wide single nucleotide polymorphisms (SNPs. The RILs from the cross between the maintainer line Zhenshan97B and the restorer line Minghui63 (both parents of the elite hybrid Shanyou63, the classical hybrid of three-line system) was used to create the subsequent immortalized $\mathrm{F}_{2}$ population, which enabled the comprehensive evaluations of the genetic contributions of dominance, over-dominance and epistatic effects across the whole rice genome (Liu et al., 2020). Otherwise, dominance effects are not fixable due to segregation and late selection may be fruitful for the selection of genotypes for the next generation of the future breeding studies to develop new rice varieties (Ashfaq et al., 2012). Utharasu \& Anandakumar (2013) found that both additive and non- additive gene action were found to control the expression of the traits under study. The magnitude of combining ability revealed non-additive genetic variance was higher than the additive variance for all the studied traits. Gaballah and Abdallah (2015) illustrated non-additive gene effects for grain yield and its components. Hijam et al. (2019) observed importance of both additive and nonadditive gene effects for grain yield and yield contributing characters studied. 
The variances of SCA were higher than the GCA for all traits (Table 6) and ratio of GCA/ SCA variances were less than unity which reported preponderance of non-additive gene action in the inheritance of respective traits. It interprets greater importance of non-additive gene action in its expression and exploitation for traits through hybrid breeding (Tan et al., 2018). The ratios of GCA/SCA were less than unity in all studied characters except days to maturity and no. of panicles/plant, indicating that dominance gene effects were more important than additive gene effects in the expression of most traits (Zaazaa and Anis, 2014).

Ganapati et al. (2020) reported the plant height, number of filled grain panicle $e^{-1}$, number of grain panicle $^{-1}$ and dominant effects for yield hill ${ }^{-1}$, yield tiller ${ }^{-1}$ and 1000 grain mass have association to yield, governed by additive gene effect. Bano and Singh (2019) showed that both the additive and non-additive genetic variance exhibited importance for expression of days to $50 \%$ flowering, days to maturity, plant height and effective tillers/ plant.

The relative contribution of lines, testers and their interaction on expression of fifteen traits studied (Fig.3) showed the prevalence of additive gene action in panicle length, panicle mass and 100-grain mass refers to the lines contributed by more positive alleles while the testers contributed by more positive alleles in panicle exertion, panicle mass, fertility percentage and grain yield. Days to heading, flag leaf angle, chlorophyll content, plant height, flag leaf area, number of panicles/ plant, grain type, phenotypic acceptability and apparent heterosis traits contributed by line $\times$ tester interaction depending on the respective crosses were subjective to non-additive gene action. Istipliler et al. (2015) revealed the line $\times$ tester interaction contributed to combinations variances was found much more than lines and testers, individually.

The relative contribution of line, tester and combinations of line $\times$ tester interaction of ten traits were calculated and found that panicle mass contributed the highest $(69.53 \%)$ followed by thousand grain mass (63.62\%), yield per plant (54.76\%), panicle per meter square $51.52 \%$ in their hybrids (Akter et al., 2010).

The parents, 'WTSC9059', 'Sakha101', 'Sakha102' and 'Sakha108' were recognized as good general combiners due to their maximum positive GCA effect values for most traits and could be utilized in breeding program to enhance grain yield and its related traits. Eltahawy et al. (2020)but also performance of grain quality traits of F2 bulk population which is the commodity consumed by humans. In order to make GCA improvement for quality traits in parents of hybrid rice by molecular marker assisted selection feasible, genome-wide GCA loci for quality traits in parents were detected through associa- tion analysis between the effects of GCA and constructed single nucleotide polymorphism linkage disequilibrium blocks (SNPLDBs reported the general combining ability (GCA) of parents in hybrid rice affects playing vital role in both heterotic level of grain yield and other important agronomic traits. Considering the exhibition of useful GCA effects by the testers were identified as good general combiners for the traits concerned (Hossain et al., 2018).

The crosses 'WTSC9039' $\times$ 'Sakha102' and 'WTSC9059' × 'Sakha105' found to be highly significant and positive SCA for number of panicle/plant and could be selected for further improving high heterosis. The hybrid combinations 'WTSC9039' × 'Sakha102', 'WTSC9039' × 'Sakha108', 'WTSC9059' × 'Sakha101', 'WTSC9059' × 'Sakha107', 'WTSC9369' × 'Sakha101', 'WTSC9369' × 'Sakha107', 'WTSC9369' × 'Sakha108', 'Longping' $\times$ 'Sakha102' and 'Longping' $\times$ 'Sakha105' described highly significant positive SCA effects for grain yield and showed high heterosis. Therefore, could be utilized for future breeding program for development of high yielding genotype. The SCA effects of the crosses for yield and its contributing characters indicated that most of the good specific cross combinations for different characters involved parents with either one or both good GCA effects. Bano and Singh (2019) reported that the three specific combiners for seed yield/plant were 'Kasturi Basmati' $\times$ 'Pusa-2517- 2-51-1', 'Pusa Sugandh-5' $\times$ 'Type-3' and 'Pusa Sugandh-5' $\times$ 'Pusa Sugandh-2'. These crosses were good specific combiners for grain yield / plant. Ganapati et al. (2020) revealed the cross combinations, which expressed high SCA effects for grain yield have invariably exhibited positive SCA effects for one or more yield related traits also.

It appears that heterosis for yield may be through heterosis for individual yield components or alternatively due to multiplication effects of non-additive gene effects of component characters. Generally, high $\times$ high, low $\times$ high and high $\times$ low general combiner parents produced good specific cross combinations. In these crosses additive $x$ additive, dominance $x$ additive and additive $\times$ dominance type of gene action was found. In cases, high $\times$ high general produced inferior cross combinations indicating epistatic type of gene action for these traits (Anis et al., 2016). The discovery of male sterile lines plays a crucial role in the utilization of rice heterosis and heterosis percent was estimated to know the possible gene action, exploit heterosis for high grain yield and associated traits. The crosses 'WTSC9059' × 'Sakha101', 'WTSC9369' × 'Sakha101', 'Longping' × 'Sakha105' and 'WTSC9039' × 'Sakha102' express superior heterosis values for grain yield. Thus, hybrids could be used for future breeding program for development grain yield and its associated traits. 
Gokulakrishnan and Kumar (2013) found the cross combinations 'IR58025A' × 'ASD19', 'IR62829A' × 'ASD16', 'PUSA3A' $\times$ 'IR42' promising for seed yield and had high percentage of standard heterosis. (Yu et al., 2020) showed that heterosis in $\mathrm{F}_{1}$ involved grain number/panicle. The back cross inbreeding lines $\mathrm{F}_{1} \mathrm{~s}$ showed an increase in grain number/panicle but a decrease in plant height compared with the back cross inbreeding lines. Abdullah et al. (2020) developed a neo-tetraploid rice line Huaduo8 with long panicles and harboring wide compatibility genes for pollen and embryo sac fertility. All the hybrids generated by Huaduo 8 produced significant high parent yield heterosis and displayed long panicles.

\section{CONCLUSION}

The combining ability of five pollinator and four EGMS lines through line $\times$ tester analyses for GY and yield related traits. Based on the results could be considering improving the DTH, NOP, Pl, FAR, HGM, FP and GT to increase GY. Specific parents with the potential to produce superior hybrids and improve the existing breeding pool were identified. The variances of SCA were higher than the GCA for all traits and ratio of GCA/ SCA variances were less than unity which reported preponderance of non-additive gene action in the inheritance of respective traits. The prevalence of additive gene action in panicle length, panicle mass and 100-grain mass refer to the lines contributed by more positive alleles while the testers contributed by more positive alleles in panicle exertion, panicle mass, fertility percentage and grain yield. Days to heading, flag leaf angle, chlorophyll content, plant height, flag leaf area, number of panicles/ plants, grain type, phenotypic acceptability and apparent heterosis traits contributed by line $\times$ tester interaction depending on the respective crosses were subjective to nonadditive gene action. Heterosis was also evident among the crosses although SCA effects did not automatically translate to better hybrid performance.

\section{REFERNCES}

Abdullah, M., Ghaleb, A., Li, C., Shahid, M. Q., \& Yu, H. (2020). Heterosis analysis and underlying molecular regulatory mechanism in a wide- compatible neo-tetraploid rice line with long panicles. BMC Plant Biology, 1-15. https://doi. org/10.1186/s12870-020-2291-z

Akanksha, \& H. K. Jaiswal. (2019). Combining ability studies for yield and quality parameters in basmati rice (Oryza sativa L .) genotypes using diallel approach Combining ability studies for yield and quality parameters in basmati rice.
Electronic Journal of Plant Breeding, 10(1), 9-17. https://doi. org/10.5958/0975-928X.2019.00002.4

Akter, A., Hasan, M. J., Begum, H., Kulsum, M. U., \& Hossain, M. K. (2010). Combining ability analysis in rice (Oryza Sativa L.) A. Bangladesh Journal Plant Breeding and Genetics, 23(2), 7-13. https://doi.org/10.3329/bjpbg.v23i2.9319

Anis, G. B., El-Mowafi, H. F., EL-Sabagh, A., \& Barutçular, C. (2016). Hybrid vigor expression for some important agronomic traits in rice using diallel method. Journal of Experimental Agriculture International, 14(3), 1-6. https://doi. org/10.9734/JEAI/2016/29742

Anis, G., El-Mowafi, H., El-Sherif, A., Freeg, H., El-Sayed, A., EL, A., \& Sabagh. (2017). Utilizing two line system in hybrid rice (Oryza sativa L.) and potential yield advantage under Egyptian conditions. Agricultural Advances, 6(3), 398-406. https://doi.org/10.14196/aa.v6i3.2375

Ashfaq M., Haider M. S., Khan, A. S., \& Allah, S. U. (2012). Breeding potential of the basmati rice germplasm under water stress condition. African Journal of Biotechnology, 11(25), 6647-6657. https://doi.org/10.5897/ajb11.3698

Bano, D. A., \& Singh, S. P. (2019). Combining ability studies for yield and quality traits in aromatic genotypes of rice (Oryza sativa. L.). Electronic Journal of Plant Breeding, 10(2), 341352. https://doi.org/10.5958/0975-928X.2019.00044.9

Chang, Z., Chen, Z., Wang, N., Xie, G., Lu, JOURNAL, Yan, W., Zhou, JOURNAL, Tang, X., \& Deng, X. (2016). Construction of a male sterility system for hybrid rice breeding and seed production using a nuclear male sterility gene. Proceedings of the national academy of sciences of the united states of america , 1-6. https://doi.org/10.1073/pnas.1613792113

Dan, Z., Chen, Y., Zhao, W., Wang, Q., \& Huang, W. (2019). Metabolome-based prediction of yield heterosis contributes to the breeding of elite rice. Life Science Alliance, 3(1), 1-10. https://doi.org/10.26508/lsa.201900551

Eltahawy, M. S., Ali, N., Zaid, I. U., Li, D., Abdulmajid, D., Bux, L., Wang, H., \& Hong, D. (2020). Association analysis between constructed SNPLDBs and GCA effects of 9 quality-related traits in parents of hybrid rice (Oryza sativa L.). BMC Genomics, 21(1), 1-16. https://doi.org/10.1186/ s12864-019-6428-0

Fehr, W. R. (1987). Heterosis In: Principles of cultivar development: Theory and Techniques (Vol. 1). Macmillan Publishing Company. New York.

Ganapati, R. K., Rasul, M. G., Sarker, U., Singha, A., \& Faruquee, M. (2020). Gene action of yield and yield contributing traits of submergence tolerant rice (Oryza sativa L.) in Bangladesh. Bulletin of the National Research Centre, 44(1). https:// doi.org/10.1186/s42269-019-0261-0

Gokulakrishnan, JOURNAL, \& Kumar, B. S. (2013). Heterotic studies using cytoplasmic male sterile lines for enhancing yield attributed traits in rice ( Oryza sativa L .). International Journal of Current Research, 5(01), 027-029.

Gramaje, L. V., Caguiat, JOURNAL D., Enriquez, JOURNAL O. S., dela Cruz, Q. D., Millas, R. A., Carampatana, JOURNAL E., \& Tabanao, D. A. A. (2020). Heterosis and combining ability analysis in CMS hybrid rice. Euphytica, 216(1), 1-22. https://doi.org/10.1007/s10681-019-2542-y

Griffiths, A., Miller, JOURNAL, Suzuki, D., Lewontin, R., \& 
Gelbart, W. (2000). An introduction to genetic analysis, 7th edn. W.H. Freeman, p 860.

Hijam, C., Singh, N. B., \& Laishram, JOURNAL M. (2019). Diallel analysis of yield and its important components in aromatic rice (Oryza sativa L. ). Indian journal of agricultural research, 53(1), 67-72. https://doi.org/10.18805/ IJARe.A-5141

Hossain, M. A., Hasan, M. JOURNAL, Kulsum, M. U., \& Sarker, M. M. (2018). Identification of potential maintainer and restorer lines using testcross hybrids. Turkish Journal of Agriculture - Food Science and Technology, 6(8), 953. https://doi. org/10.24925/turjaf.v6i8.953-962.1481

IRRI. (2002). Standard evaluation system for rice (SES).

Istipliler, D., Ilker, E., Aykut Tonk, F., Civi, G., \& Tosun, M. (2015). Line $\times$ tester analysis and estimating combining abilities for yield and some yield components in bread wheat. Turkish Journal of Field Crops, 20(1), 72-77. https:// doi.org/10.17557/.57234

Kempthorne, O. (1957). An introduction to genetic statistics. New York (USA): John Wiley and Sons, Inc., and London (UK): Chapman and Hall, Ltd.

Khush, G. S., Brar, D. S., \& Ardy, B. (2003). Advances in Rice Genetics. https://doi.org/10.1142/9789812814319_0055

Lan, S. H. E. N., Guojun, D. O. N. G., Yu, Z. H., Guocheng, H. U., Qiang, Z. H., Guanglian, H. U., Bo, X. U., Deyong, R. E. N., Jiang, H. U., Li, Z. H. U., Zhenyu, G. A. O., Guangheng, Z. H., Longbiao, G. U. O., Dali, Z. E. N. G., \& Qian, Q. I. A. N. (2019). Rapid creation of new Photoperiod- / Thermo-sensitive genic male-sterile rice materials by CRISPR / Cas9 System. Rice Science, 26(2), 129-132. https://doi. org/10.1016/Journalrsci.2018.12.006

Li, R., Li, M., Ashraf, U., Liu, S., \& Zhang, JOURNAL (2019). Exploring the relationships between yield and yield-related traits for rice varieties released in China from 1978 to 2017. Frontiers in plant science, 10(543), 1-12. https://doi. org/10.3389/fpls.2019.00543

Liu, JOURNAL, Li, M., Zhang, Q., Wei, X., \& Huang, X. (2020). Exploring the molecular basis of heterosis for plant breeding. Journal of Integrative Plant Biology, 62(3), 287-298. https://doi.org/10.1111/jipb.12804

Peng, S., Khush, G. S., Virk, P., Tang, Q., \& Zou, Y. (2008). Progress in ideotype breeding to increase rice yield potential.
Field Crops Research, 108, 32-38. https://doi.org/10.1016/ Journalfcr.2008.04.001

Singh, R. K., \& Chaudhary, B. D. (1985). Biometrical Methods in Quantitative Genetic analysis. Kalyani Publ., Ludhiana, New Delhi, p. 342.

Singh, R., \& Ram, L. (2012). Ideal hybrid rice seed production package : An overview. Indian Research Journal of Extension Education, II, 244-251.

Ullah Zaid, I., Tang, W., He, JOURNAL, Ullah Khan, S., \& Hong, D. (2019). Association analysis uncovers the genetic basis of general combining ability of 11 yield-related traits in parents of hybrid rice. AoB PLANTS, 11(1), 1-15. https:// doi.org/10.1093/aobpla/ply077

Verma, O., \& Srivastra, V. (2004). Genetic component and com- bining ability analyses in relation to heterosis for yield and associated traits using three diverse rice-growing ecosys- tems. Crop Science, 88(2-3), 91-102. https://doi. org/10.1016/S0378-4290(03)00080-7

Wongpatsa, U., \& Kaveeta, L. (2014). Effects of temperature on male sterility of two inbred lines of hybrid rice. Natural Sciences, 48, 525-533.

Wynne, JOURNAL C., Emery, D., \& Rice, P. (1970). Combining ability estimation in Arachis hypogaea L. 11. Field performance of F1 hybrids. Crop Science, 10, 713-715. https://doi. org/10.2135/cropsci1970.0011183X001000060036x

Xie, F. (2018). Shanyou 63 : an elite mega rice hybrid in China. Rice, 11(17), 1-6. https://doi.org/10.1186/s12284-0180210-9

Yu, Y., Zhu, M., Cui, Y., Liu, Y., Li, Z., \& Jiang, N. (2020). Genome sequence and QTL analyses using backcross recombinant inbred lines ( BILs) and BILF 1 lines uncover multiple heterosis-related loci. International Journal of Molecular Sciences, 21(780), 1-10. https://doi.org/10.3390/ ijms 21030780

Zaazaa, E. I., \& Anis, G. B. (2014). Heterosis, combining ability and phenotypic correlation for some economic traits in rice (Oryza sativa L.). Middle East Journal of Agriculture Research, 3(4), 1155-1162.

Zhang, Y., Tang, Q., Zou, Y., Li, D., Qin, JOURNAL, Yang, S., Chen, L., Xia, B., \& Peng, S. (2009). Yield potential and radiation use efficiency of "super" hybrid rice grown under subtropical conditions. Field Crops Research, 114, 91-98. https://doi.org/10.1016/Journalfcr.2009.07.008. 